\title{
Early Weight Loss Percentile Charts in Exclusively Breastfed Infants According to Mode of Delivery
}

\section{Sadece Anne Sütü ile Beslenen Bebeklerde Doğum Şekline Göre Erken Kilo Kaybı Persentil Eğrileri}

\author{
Bahar Kural $^{1 \oplus}$, Tijen Eren ${ }^{2} \oplus$, Gulbin Gokcay ${ }^{3 \oplus}$ \\ ${ }^{1}$ Istanbul University Institute of Health Sciences and Institute of Child Health Social Pediatrics Doctoral Programme, Istanbul, Turkey \\ ${ }^{2}$ Department of Pediatrics, Koç University Faculty of Medicine, Istanbul, Turkey \\ ${ }^{3}$ Istanbul University Institute of Child Health, Department of Social Pediatrics, Istanbul, Turkey
}

Received: 8 May 2020 / Accepted: 8 June 2020 / Publication date: 26 June 2020

Cite as: Kural B, Eren T, Gokcay G. Early weight loss percentile charts in exclusively breastfed infants according to mode of delivery. Med J Bakirkoy 2020;16(2):182-9.

\section{ABSTRACT}

Objective: Early weight loss percentile charts can be used to determine the expected weight loss of newborns. Mode of delivery has a marked effect on weight loss in the immediate postpartum period. The aim in the present study was to construct weight loss percentile charts according to mode of delivery in exclusively breastfed, healthy term infants during hospital stay.

Method: Weight loss in a large Turkish cohort of infants, born between January 1, 2011 and December 31, 2014, was evaluated retrospectively. Data on healthy, term and exclusively breastfed neonates during the immediate postpartum hospital stay were collected. Weight change percentile charts were plotted according to mode of delivery.

Results: The study encompassed 3247 exclusively breastfed neonates. Of infants $48.1 \%$ were girls. Mean gestational age was $38.94 \pm 0.84$

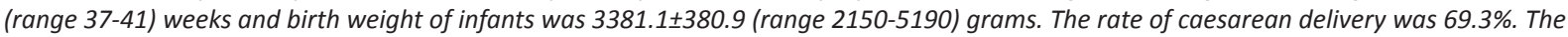
time of hospital stay of infants born by caesarean delivery was significantly longer than infants born vaginally. The frequency of weight measurements of infants showed a statistically significant difference according to the type of delivery. Weight loss as a percentage of birthweight for infants born by caesarean delivery were significantly greater at 24, 48, 72 and 84 hours after birth compared to those born via vaginal delivery.

Conclusion: Plotted percentile charts according to mode of delivery will enable prediction of early weight loss immediately post-partum. In addition, these percentile charts will help to reassure mothers and encourage breastfeeding exclusivity.

Keywords: early weight loss, percentile charts, exclusive breastfeeding

Öz

Amaç: Erken kilo kaybı persentil eğrileri, yenidoğanlarda beklenen kilo kaybını belirlemek için kullanılabilir. Doğum şekli, hemen doğum sonrası dönemde kilo kaybı üzerinde belirgin bir etkiye sahiptir. Bu çalışmada amaç, sadece anne sütü ile beslenen, sağlıklı, term bebeklerde hastanede kalış sırasında doğum şekline göre kilo kaybı persentil eğrilerini oluşturmaktır.

Yöntem: Geniş bir Türk bebek kohortunda, 1 Ocak 2011 - 31 Aralık 2014 tarihleri arasında doğanların kilo kaybı geriye dönük olarak değerlendirilmiştir. Doğum sonrası hastanede kalış süresi boyunca sağlıklı, term ve sadece anne sütü ile beslenen yenidoğanlara ilişkin veriler toplanmıștır. Ağırlık değişim persentil eğrileri doğum şekline göre çizilmiștir.

Bulgular: Çalışma sadece anne sütü ile beslenen 3247 yenidoğanı kapsamaktadır. Bebeklerin \% 48,1'i kızdır. Ortalama gebelik süresi $38,94 \pm$ 0,84 (37-41) hafta ve bebeklerin doğum ağırlığı 3381,1 \$380,9 (2150-5190) gramdır. Sezaryenle doğum oranı \% 69,3'tür. Sezaryen ile doğmuş bebeklerin hastanede kalış süresi vajinal doğum ile doğan bebeklere göre anlamlı olarak daha uzundur. Bebeklerin ağırlık ölçümlerinin sıklığı, doğum şekline göre istatistiksel olarak anlamlı bir farklılık göstermiştir. Sezaryen ile doğmuş bebekler için doğum ağırlığına oranla yüzdesel olarak kilo kaybı, doğumdan 24, 48, 72 ve 84 saat sonra, vajinal doğumla doğanlara göre anlamlı olarak daha yüksektir.

Sonuç: Doğum şekline göre çizilen persentil eğrileri, doğumdan hemen sonra erken kilo kaybının tahmin edilmesini sağlayacaktır. Ek olarak, bu persentil eğrileri anneleri rahatlatmaya ve bebeklerini sadece anne sütü ile beslemeye teşvik etmeye yardımcı olacaktır.

Anahtar kelimeler: erken ağırlık kaybı, persentil eğrileri, sadece anne sütü ile beslenme

Corresponding Author:

drbahsal@yahoo.com
B. Kural 0000-0001-9528-1009

T. Eren 0000-0001-9650-3734

G. Gokcay 0000-0003-1042-0407

(C) Telif hakkı Sağlık Bilimleri Üniversitesi Bakırköy Dr. Sadi Konuk Eğitim ve Araştırma Hastanesi'ne aittir. Logos Tıp Yayıncılık tarafindan yayınlanmaktadır. Bu dergide yayınlanan bütün makaleler Creative Commons Atff-GayriTicari 4.0 Uluslararası Lisansı ile lisanslanmıştır.

(c) Copyright Health Sciences University Bakırköy Sadi Konuk Training and Research Hospital. This journal published by Logos Medical Publishing. Licenced by Creative Commons Attribution-NonCommercial 4.0 International (CC BY-NC 4.0) 


\section{INTRODUCTION}

The World Health Organization (WHO), United Nations International Children's Fund (UNICEF) and various health organisations dealing with children's health, all advocate infants be exclusively breastfed for the first six months of life to achieve optimal growth, development and health ${ }^{(1)}$. Normal postpartum physiologic weight loss is defined as $5-7 \%$ loss of the birth weight ${ }^{(2)}$. Various early weight loss limits have been described in healthy infants such that losing $7-10 \%$ of birth weight is seen as common $(3,4)$. There are also known morbidities related to early weight loss, such as hypoglycaemia, hyperbilirubinemia and hypernatremic dehydration ${ }^{(5,6,7)}$.

In an earlier study from this center, the risk factors for early weight loss in infants was investigated in the same cohort presented here and mode of delivery was identified as a significant factor ${ }^{(8)}$. Delayed lactogenesis, delayed time of feeding initiation, postoperative pain, and maternal comorbidities leading to emergency caesarean delivery may cause breastfeeding difficulties and increase weight loss in newborns ${ }^{(9)}$. During caesarean delivery, it is normal to use intravenous fluids which will affect the birth weight and subsequent weight loss of the neonate (4). Excessive weight loss after birth may cause anxiety and reduced breastfeeding success ${ }^{(10,11,12)}$. Early supplementation with formula will lead to failure to achieve an exclusive breastfeeding target for the first six months of life ${ }^{(13)}$.

The first early weight loss nomograms were published by Flaherman et al. ${ }^{(14)}$. The study encompassed nearly 109,000 infants in the USA. One study from Turkey, examined the relationship between gender, ethnicity and early weight loss of breastfed and term infants up to 72 hours after birth ${ }^{(15)}$. Management plans for infants with excess weight loss generally focus on promoting weight gain but do not always focus on promotion of consistent, evidence-based infant feeding support to parents ${ }^{\left({ }^{9}\right)}$. By using percentiles, clinicians may estimate weight loss patterns on a time-interval basis and identify infants who are at risk for excessive early weight loss ${ }^{(14)}$. In addition, parents can be shown the pattern and estimated weight loss of their babies according to mode of delivery during hospital stay. Parents can thus be reassured about weight change patterns and this information can be useful for promoting exclusive breastfeeding.

The aim of this study was to develop early weight loss percentile charts according to delivery mode in a cohort of exclusively breastfed healthy infants in the immediate post-partum hospital stay in Turkey.

\section{MATERIALS and METHODS}

This retrospective, cohort study was based on the evaluation of postnatal hospital records of newborns. Changes in weight for healthy, term, exclusively breastfed newborns after delivery and during hospital stay were analysed.

Infants delivered in a private hospital between 1 January 2011 and 31 October 2014 were eligible for inclusion in the study. Hospital patients belonged to high and very-high income level groups. All mothers were offered antenatal (30-36 weeks of gestation) 'breastfeeding education' during pregnancy. All neonates were evaluated by a paediatrician immediately after birth. Skin-to-skin contact and breastfeeding within one hour after delivery were early goals. A family medicine specialist, who was also an International Board-Certified Lactation Consultant (IBCLC), evaluated all mother-infant pairs during hospital stay in order to achieve breastfeeding exclusivity.

A total of 3247 term, singleton neonates with uneventful perinatal periods were eligible for inclusion in the study. Exclusion criteria were: infants who were non-breastfed; any formula use; gestational age $<37$ weeks or $\geq 42$ weeks; presence of any metabolic or congenital disease; Neonatal Intensive Care Unit (NICU) admittance and/or APGAR score lower than 7; and multiple births (twins or triplets). Birth weight was not considered as an exclusion criterion. Flowchart of the study was given in Figure 1. Routine weight measurements were performed until discharge, the first one being immediately in the delivery room (birth weight) and daily thereafter. All weight measurements were done by a trained nurse when infants were naked. The electronic digital platform scales accurate to 5 grams were used. The scales were calibrated in accordance with hospital policy. All infants were visited by a paediatrician and IBCLC daily. 
When weight loss reached or exceeded $7 \%$ of birth weight, measurements were taken at least every 12 hours and re-evaluation of breastfeeding technique and additional breastfeeding consultancy was provided. If latch was not successful, manually expressed milk was given by cup feeding. For the purpose of this study, those babies who were given expressed mother's own milk (MOM) were still assumed to be exclusively breastfed.

Retrospective data were collected from postnatal hospital records of neonates. Infants were grouped according to mode of delivery. Ethical and institutional approvals were obtained.

Number Cruncher Statistical System 2007 (NCSS, Kaysville, UT, USA) was used for statistical analysis. In analysis descriptive statistical methods including mean, standard deviation, median, range (minimum and maximum), frequency and ratio were used. Quantitative data were investigated using visual (graph plots) and analytical methods (Shapiro-Wilk's test) to determine whether or not they were normally distributed. Student's t test was used for comparing two groups of normally distributed variables, and Mann Whitney $U$ test was used for comparing groups when one or both were non-parametric. Pearson Chi-Square test and Fisher's Exact test were employed for comparison of qualitative data. All results were evaluated at the $95 \%$ confidence interval, and $p<0.05$ was assumed to indicate significance.

\section{RESULTS}

Hospital records of 3247 healthy, term neonates were evaluated for this study. The proportion of males was $51.9 \%(n=1684)$. Maternal age varied between 19 and 52 , median was 34 years. Mean gestational age and birth weight of infants were $38.94 \pm 0.84$ (range 37-41) weeks and 3381.1 \pm 380.9 (range 2150-5190) grams respectively. All neonates were exclusively breastfed after delivery for the duration of hospital stay. Maternal age, gestational week and birth weight distributions are given in Table 1.

Mother/baby pairs were divided into two groups by mode of delivery (caesarean delivery $n=2249$ and normal vaginal delivery $\mathrm{n}=998$ ) and the rate of caesarean delivery was $69.3 \%$. There was a statistical significance between maternal age and mode of delivery $(p<0.01)$; mothers who delivered by caesarean delivery were significantly older than women in the vaginal delivery group (34.2 vs 32.8 years, $p=0.001$ ). Baby gender by mode of delivery did not yield statistical significance $(p>0.05)$. The gestational age of infants born vaginally was significantly higher than infants born via caesarean delivery $(p=0.001)$. There was a statistically significant difference between birth weights according to mode of delivery $(p=0.003)$; infants born by caesarean delivery were heavier than those born vaginally.

The mean duration of hospital stay was $63.25 \pm 15.95$ hours in the whole cohort. The time of hospital stay of infants born by caesarean delivery was significantly longer than infants born vaginally $(p=0.001)$.

The number of weight measurements of neonates included in the study are given in Table 2. The frequency of weight measurements of infants showed a statistically significant difference according to the type of delivery $(p=0.001)$. Excluding birth weight measurement, infants born by vaginal delivery were more likely to have their weight measured $\leq 3$ times while infants born by caesarean delivery were more likely to be weighed $\geq 4$ times.

Time intervals and early weight loss percentages of newborns are given in Table 3. Weight loss proportions for infants born by caesarean delivery compared to infants born via vaginal delivery were significantly higher at $24^{\text {th }}$ hour $(p=0.001), 48^{\text {th }}$ hour $(p=0.001), 72^{\text {nd }}$ hour $(p=0.001)$ and $84^{\text {th }}$ hour $(p=0.011)$.

In all cases, for caesarean and vaginal deliveries; $95 \%, 90 \%, 75 \%$ and $50 \%$ weight loss percentile values over time $(24,48,72$ and 84 hours after delivery) are given in Table 4 . Using this data early weight loss percentages were plotted and weight loss percentile charts were created. The charts for weight loss percentile for exclusively breastfed infants delivered by caesarean delivery and normal vaginal delivery are shown in Figures 2 and 3, respectively. 
Table 1. Demographic and clinical characteristics of the mothers and infants by mode of delivery

\begin{tabular}{|c|c|c|c|c|c|}
\hline & & $\begin{array}{l}\text { Total } \\
\mathrm{n}(\%)\end{array}$ & $\begin{array}{c}\text { Caesarean } \\
(n=2249) \\
n(\%)\end{array}$ & $\begin{array}{c}\text { Vaginal }(n=998) \\
n(\%)\end{array}$ & $\mathbf{p}$ \\
\hline \multirow[t]{6}{*}{ Maternal age } & Median (range) & $34(19-52)$ & $34(20-52)$ & $33(19-46)$ & ${ }^{a} 0.001 * *$ \\
\hline & Mean $\pm S D$ & $33.75 \pm 4.0$ & $34.17 \pm 4.1$ & $32.82 \pm 3.8$ & \\
\hline & $\leq 30$ & $664(20.4)$ & $401(17.8)$ & $263(26.4)$ & \\
\hline & 31-35 & $1536(47.3)$ & $1033(45.9)$ & $503(50.4)$ & \\
\hline & $36-40$ & 895 (27.6) & $686(30.5)$ & $209(20.9)$ & \\
\hline & $\geq 41$ & $152(4.7)$ & $129(5.7)$ & $23(2.3)$ & \\
\hline \multirow[t]{2}{*}{ Infant gender } & Boy & 1684 (51.9) & 1178 (52.4) & $506(50.7)$ & ${ }^{c} 0.377$ \\
\hline & Girl & $1563(48.1)$ & $1071(47.6)$ & $492(49.3)$ & \\
\hline \multirow{4}{*}{$\begin{array}{l}\text { Gestation } \\
\text { al age (weeks) }\end{array}$} & Median (range) & $39(37-41)$ & $38.7(37-41)$ & $39.3(37-41)$ & ${ }^{a} 0.001 * *$ \\
\hline & Mean $\pm S D$ & $38.9 \pm 0.8$ & $38.8 \pm 0.8$ & $39.3 \pm 0.9$ & \\
\hline & $37-38$ & 1609 (49.6) & $1289(57.3)$ & $320(32.1)$ & \\
\hline & $\geq 39$ & $1638(50.4)$ & $960(42.7)$ & $678(67.9)$ & \\
\hline \multirow{6}{*}{$\begin{array}{l}\text { Birth weight } \\
\text { (grams) }\end{array}$} & Median (range) & 3370 (2150-5190) & $3380(2150-5190)$ & 3350 (2330-4700) & ${ }^{a} 0.003 * *$ \\
\hline & Mean $\pm S D$ & $3381.1 \pm 380.9$ & $3394.2 \pm 385.3$ & $3351.5 \pm 369.1$ & \\
\hline & $2000-2500$ & $17(0.5)$ & $9(0.4)$ & $8(0.8)$ & \\
\hline & 2501-2999 & $472(14.5)$ & 309 (13.7) & $163(16.3)$ & \\
\hline & 3000-3999 & $2572(79.2)$ & $1783(79.3)$ & 789 (79.1) & \\
\hline & $\geq 4000$ & $186(5.7)$ & 148 (6.6) & $38(3.8)$ & \\
\hline \multirow{2}{*}{$\begin{array}{l}\text { Duration of hospital } \\
\text { stay (hours) }\end{array}$} & Median (range) & $72(12-84)$ & $72(24-84)$ & $48(12-84)$ & ${ }^{a} 0.001 * *$ \\
\hline & Mean $\pm S D$ & $63.25 \pm 15.95$ & $71.03 \pm 7.66$ & $45.71 \pm 15.87$ & \\
\hline
\end{tabular}

a Student $t$ Test

${ }^{b}$ Mann Whitney $U$ Test

c Pearson Chi-Square Test

${ }^{*} p<0.05,{ }^{* *} p<0.01$

Table 2. Number of weight measurements by mode of delivery.

\begin{tabular}{lccc}
\hline $\begin{array}{l}\text { Number of weights recorded } \\
\text { after birth weight }\end{array}$ & $\begin{array}{c}\text { Caesarean } \\
(\mathbf{n = 2 2 4 9 )} \\
\mathbf{n}(\%)\end{array}$ & $\begin{array}{c}\text { Vaginal } \\
(\mathbf{n = 9 9 8 )} \\
\mathbf{n}(\%)\end{array}$ & $\boldsymbol{p}$ \\
\hline 1 & $0(0)$ & $5(0.5)$ & ${ }^{d} \mathbf{0 . 0 0 1 * *}$ \\
2 & $10(0.4)$ & $255(25.6)$ & \\
3 & $152(6.8)$ & $578(57.9)$ & \\
4 & $1924(85.5)$ & $145(14.5)$ & \\
5 & $163(7.2)$ & $15(1.5)$ & \\
\hline
\end{tabular}

${ }^{d}$ Fisher Freeman Halton Test

${ }^{* *} p<0,01$

\section{DISCUSSION}

The study showed that infants born by caesarean delivery and exclusively breastfed, had significantly higher early weight loss in the immediate post-partum period compared to vaginally delivered infants. Weight loss percentiles during the first days of life according to mode of delivery were developed using the collected data (Figures 2 and 3). It was demonstrated that expected weight loss differences between type of delivery mode continued over the first few days of life.

There has been a worldwide increase in the rates of caesarean deliveries ${ }^{(16)}$. The latest caesarean delivery rate reported by the Turkish Demographic and Health Survey of 2018 was 52\% (17). The WHO has stated that no robust evidence existed for ideal caesarean delivery rates ${ }^{(16)}$. In another study from Turkey, where early weight loss in infants was investigated, the caesarean delivery rate was $47 \%$ in the setting of a teaching hospital of the Turkish Ministry of Health ${ }^{(15)}$. A recent study from Brazil showed that the caesarean delivery in the private sector was more than twice the rate in the public sector $(87.9 \%$ versus $42.9 \%$, respectively) ${ }^{(18)}$. Saki et al. showed that $80 \%$ of mothers who lived in high income families had caesarean delivery and this study has reinforced the view that women from wealthier families tend to opt for caesarean delivery ${ }^{(19)}$. The rate of caesarean delivery in our study was quite high 
Table 3. Weight loss proportions of the study group by mode of delivery during hospital stay.

\begin{tabular}{|c|c|c|c|c|c|}
\hline Time (hours) & Mode of delivery & $\mathbf{n}$ & Median (Min-Max) & Mean $\pm S D$ & ${ }^{a} p$ \\
\hline \multirow[t]{2}{*}{24} & Caesarean & 2249 & $4.1(0-10.3)$ & $-4.06 \pm 1.54$ & $0.001 * *$ \\
\hline & Vaginal & 993 & $3.1(0-9.5)$ & $-3.24 \pm 2.03$ & \\
\hline \multirow[t]{2}{*}{48} & Caesarean & 2239 & $7.3(0.4-13.4)$ & $-7.22 \pm 1.49$ & $0.001 * *$ \\
\hline & Vaginal & 738 & $5.8(0-11.6)$ & $-5.78 \pm 1.65$ & \\
\hline \multirow[t]{2}{*}{72} & Caesarean & 2087 & $7.6(0.3-13.1)$ & $-7.54 \pm 2.06$ & $0.001 * *$ \\
\hline & Vaginal & 160 & $6.8(1.2-11.9)$ & $-6.71 \pm 1.98$ & \\
\hline \multirow[t]{2}{*}{84} & Caesarean & 163 & $6.9(0.9-11.1)$ & $-6.71 \pm 2.29$ & $0.011 *$ \\
\hline & Vaginal & 15 & $5.3(0-8.1)$ & $-5.13 \pm 2.38$ & \\
\hline
\end{tabular}

${ }^{a}$ Student $t$ Test

${ }^{*} p<0.05,{ }^{*} p<0.01$

Table 4. Weight loss percentiles of study group and by mode of delivery.

\begin{tabular}{|c|c|c|c|c|c|c|}
\hline \multirow[b]{2}{*}{ Mode of delivery } & \multirow[b]{2}{*}{ Time (h) } & \multicolumn{5}{|c|}{ Weight loss (\%) } \\
\hline & & $\mathrm{n}$ & $95 \%$ & $90 \%$ & $75 \%$ & $50 \%$ \\
\hline \multirow[t]{4}{*}{ Whole cohort } & 24. & 3242 & -6.53 & -5.92 & -4.97 & -3.91 \\
\hline & 48. & 2977 & -9.42 & -8.87 & -8.00 & -6.97 \\
\hline & 72. & 2247 & -10.75 & -10.03 & -8.92 & -7.58 \\
\hline & 84. & 178 & -10.04 & -9.51 & -8.28 & -6.88 \\
\hline \multirow[t]{4}{*}{ Caesarean } & 24. & 2249 & -6.46 & -5.90 & -5.03 & -4.12 \\
\hline & 48. & 2239 & -9.56 & -9.04 & -8.24 & -7.29 \\
\hline & 72. & 2087 & -10.77 & -10.07 & -8.97 & -7.64 \\
\hline & 84. & 163 & -10.11 & -9.57 & -8.38 & -6.94 \\
\hline \multirow[t]{4}{*}{ Vaginal } & 24. & 993 & -6.71 & -5.95 & -4.72 & -3.08 \\
\hline & 48. & 738 & -8.28 & -7.74 & -6.94 & -5.79 \\
\hline & 72. & 160 & -9.83 & -9.15 & -8.02 & -6.83 \\
\hline & 84. & 15 & -7.98 & -7.68 & -7.17 & -5.29 \\
\hline
\end{tabular}

Table 5. Studies on early weight loss in exclusively breastfed infants.

\begin{tabular}{|c|c|c|c|c|c|c|c|c|}
\hline \multirow[b]{2}{*}{$\begin{array}{l}\text { Data period } \\
\text { Delivery type }\end{array}$} & \multicolumn{2}{|c|}{$\begin{array}{l}\text { Falherman et al. (14) } \\
\text { 2009-2013 }\end{array}$} & \multicolumn{2}{|c|}{$\begin{array}{l}\text { Samayan et al. }{ }^{(23)} \\
\text { Aug-Oct } 2012\end{array}$} & \multicolumn{2}{|c|}{$\begin{array}{l}\text { Hamilcıkan et al (15) } \\
\text { Jan-Aug } 2016\end{array}$} & \multicolumn{2}{|c|}{$\begin{array}{c}\text { Kural et al. } \\
\text { Jan 2011-Dec } 2014\end{array}$} \\
\hline & $\begin{array}{c}V \\
(n=83433)\end{array}$ & $\begin{array}{c}\text { CS } \\
(n=25474)\end{array}$ & $\underset{(n=55)}{V}$ & $\begin{array}{c}\text { CS } \\
(n=49)\end{array}$ & $\begin{array}{c}V \\
(n=670)\end{array}$ & $\begin{array}{c}\text { CS } \\
(n=758)\end{array}$ & $\begin{array}{c}V \\
(n=998)\end{array}$ & $\begin{array}{c}\text { CS } \\
(n=2249)\end{array}$ \\
\hline Hours & \multicolumn{6}{|c|}{ Median percentage loss (\%) } & & \\
\hline 24 & 4.2 & 4.9 & 2.2 & 3.2 & 3.88 & 4.59 & 3.1 & 4.1 \\
\hline 48 & 7.1 & 8.0 & -- & - & 5.80 & 6.00 & 5.8 & 7.3 \\
\hline 72 & 6.4 & 8.6 & 4.7 & 5.9 & 5.1 & 6.95 & 6.8 & 7.6 \\
\hline 84 & - & - & - & - & - & - & 5.3 & 6.9 \\
\hline 96 & - & 5.8 & - & - & - & - & - & - \\
\hline
\end{tabular}

(69.3\%). Our study setting was a private hospital and only private insurances were accepted.

When breastfed infants lose too much weight after birth, healthcare providers may become concerned that there is a problem with breastfeeding ${ }^{(20)}$. Studies concerning breastfeeding difficulties after birth have stated that special attention and followup are required during hospital stay (21). Besides counselling for breastfeeding techniques, the use of 


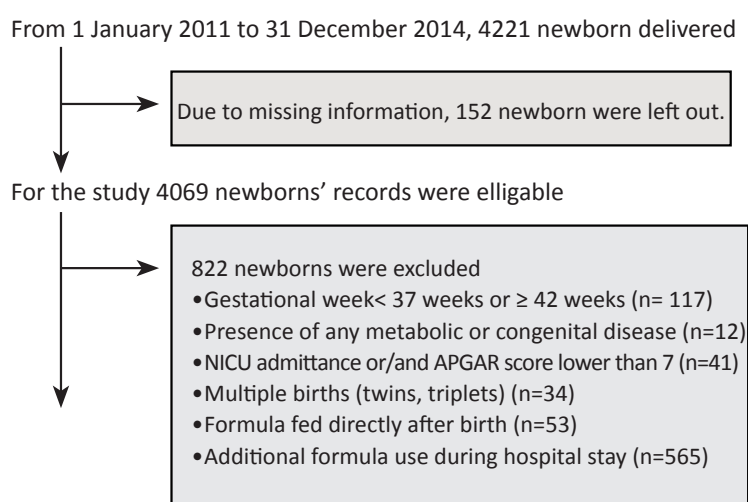

Total of 3247 newborns have been included in the study

Figure 1. Flowchart of the enrolled participants.

early weight loss percentiles can provide mothers an insight with a visual representation of how their infants are compared according to mode of delivery. This can provide reassurance that exclusive breastfeeding is perfectly adequate for nourishment.

Hourly weight loss percentiles would help clinicians to foresee expected early weight loss of infants and thus allow a personalized approach and management. Flaherman et al. attempted to identify the trajectories of breastfeeding outcomes by using early weight-loss nomograms, and concluded that the use of such nomograms might help identify infants at higher risk of cessation of exclusive breastfeeding ${ }^{(22)}$.

Samayan et al. studied early weight loss among 104 exclusively breastfed newborns prospectively in Bangalore, India. The median percentage weight loss of infants born vaginally at 24 and 72 hours was $2.2 \%$ and $4.7 \%$ respectively, while the mean weight loss for infants born by caesarean delivery was $3.2 \%$ and $5.9 \%$ at the same time points ${ }^{(23)}$. The mean weight loss percentages reported by Samayan et al. were lowest in both delivery types when compared with other studies whilst those reported by Flaherman et al. were the highest (Table 5) ${ }^{(14,23)}$. When the early weight loss studies were compared, in vaginal deliveries the highest median weight losses occurred at 48 hours, whereas in our study it occurred at 72 hours (see Table 5). The maximum mean weight loss percentages were observed at 48 hours in caesarean deliveries in our study as well as two other studies. (14,15).

Studies have shown that the length of hospital stay following caesarean delivery is higher than those following vaginal delivery ${ }^{(18)}$. The mean lengths of hospital stay were 71.0 hours for caesarean and 45.7 hours for vaginal deliveries and this difference

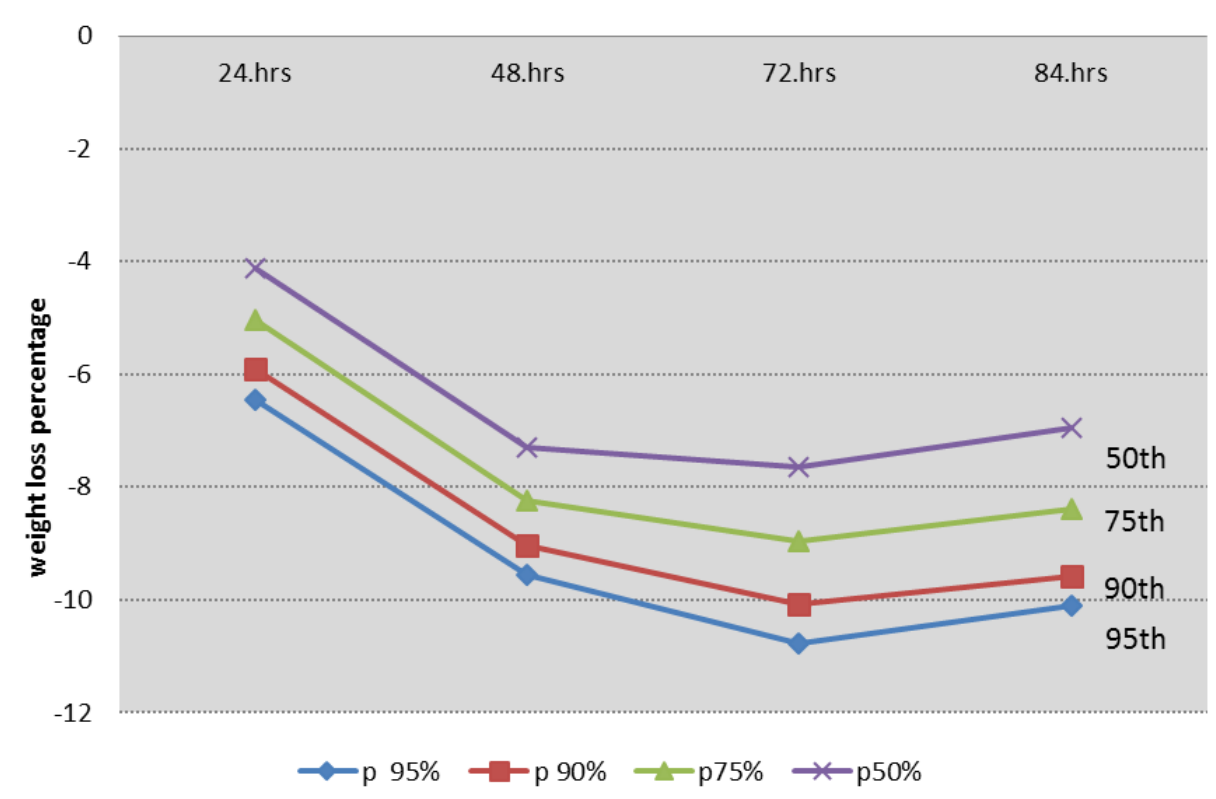

Figure 2. Weight loss percentages of exclusively breastfed infants who were born via caesarean delivery. 


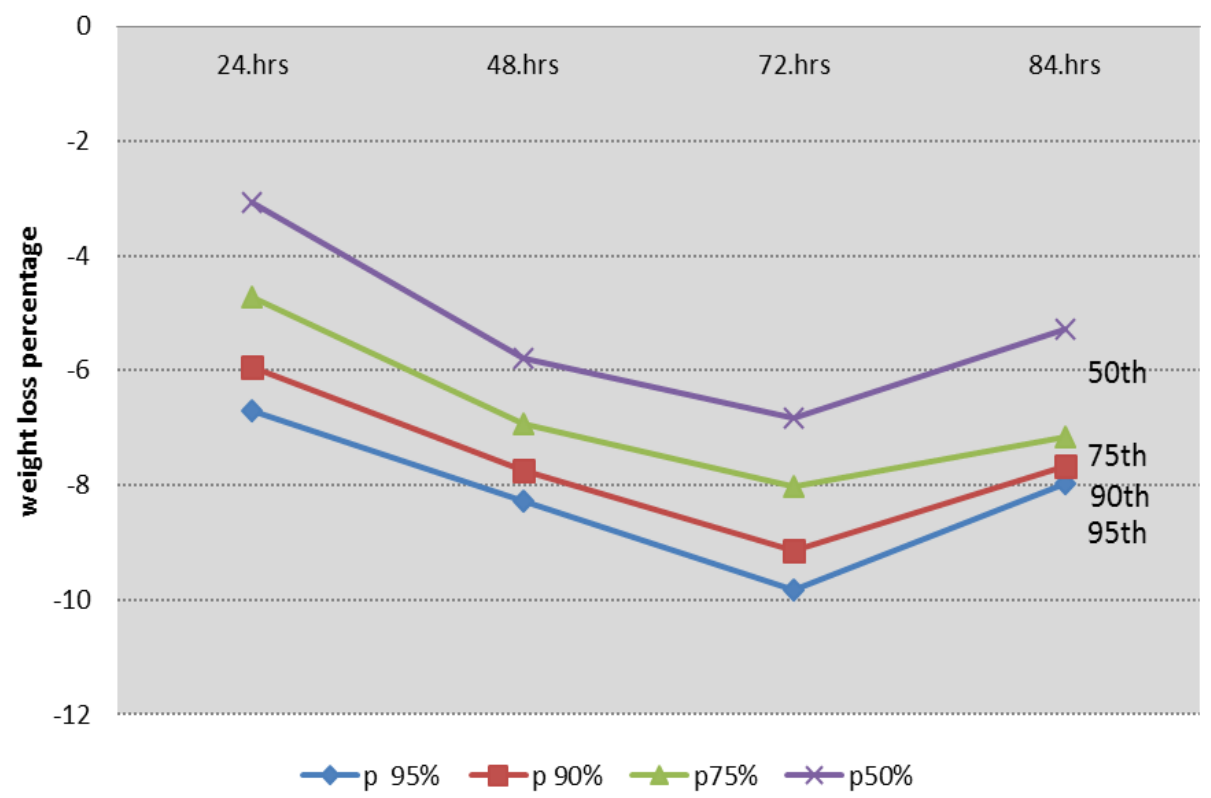

Figure 3. Weight loss percentages of exclusively breastfed infants who were born vaginally.

was statistically significant $(p=0.001)$. It has been suggested that for the establishment of successful breastfeeding, infants should be followed up for 72-96 hours after birth and that may lead to longer hospital stay after caesarean deliveries ${ }^{(21)}$. Weight measurements were continued as long as weight loss persisted. Flaherman et al. reported that $71.9 \%$ of infants born via vaginal delivery had one further weight measurement, following birthweight whereas $48.8 \%$ of infants born by caesarean deliveries had two weight measurements taken ${ }^{(14)}$. In our study $57.9 \%$ of infants born via vaginal deliveries had three further weight measurements while $85.5 \%$ of infants born via caesarean deliveries had four weight measurments. This may be due to the difference between delivery modes in the mean length of stay. Mothers and infants in Flaherman's study stayed in hospital for slightly shorter periods (2.6 and 1.6 days for caesarean and vaginal deliveries, respectively) than in our study. A prospective study to investigate the benefit of using early weight loss percentile charts in terms of breastfeeding success is planned.

Limitations of the study: As only healthy term neonates were included in the study, birth weight of infants was mostly above $\mathbf{3 0 0 0}$ grams. Information about the indication for caesarean delivery (elective or emergency) was not evaluated. Generalizability of the study may be limited, it was conducted at a private hospital where most of the infants were from high income families. One of the key strengths of the present study was the large sample size. Although the study was retrospective in nature, data was extracted precisely from hospital records.

\section{CONCLUSION}

Vaginal birth should be promoted in order to protect both maternal and neonatal health. The likely greater post-partum weight loss following caesarean delivery must be explained to those mothers who are planning to choose this delivery method. Early weight loss percentiles will have the dual benefit of predicting the expected weight loss in infants and thus reassuring mothers which, in turn, will encourage breastfeeding exclusivity.

Ethics Committee Approval: Approval was obtained from the Koç University Ethics Committee (2015.058. IRB2.024).

Conflict of Interest: The authors declared no conflict of interest.

Funding: No financial support was received.

Informed Consent: Informed consent was not obtained since the study is retrospective. 


\section{REFERENCES}

1. UNICEF/WHO. Baby-Friendly Hospital Initiative: Revised, Updated and Expanded for Integrated Care, Section 1, Background and Implementation, Preliminary version. 2009. https://apps.who.int/iris/bitstream/handle/10665/43593/97 89241594967 eng.pdf;jsessionid=62D44EC8221A7324A9488 561160A2B17? sequence=1 (Last Accessed date:22.02.2020).

2. Boies $E$, Vaucher $Y E$, and the Academy of Breastfeeding Medicine. ABM Clinical Protocol \#10: Breastfeeding the late preterm (34-36 6/7 weeks of gestation) and early term infants (37-38 6/7 weeks of gestation) Second Revision 2016. Breastfeed Med. 2016;11(10):494-500. https://doi.org/10.1089/bfm.2016.29031.egb

3. Chantry CJ, Nommsen-Rivers LA, Peerson JM, et al. Excess weight loss in first-born breastfed newborns relates to maternal intrapartum fluid balance. Pediatrics 2011;127(1):e171-9. https://doi.org/10.1542/peds.2009-2663

4. Lawrence RA, Lawrence RM. Breastfeeding: A Guide For The Medical Profession. Breastfeeding Support Groups and Community Resources. 8th Ed. W.B. Saunders, Mosby, Churchill:Elsevier; 2016.

5. Taylor JA, Impson EA. Categorizing weight loss in breastfed infants: A good first step. Pediatrics 2015; 135(1);e174-e175. https://doi.org/10.1542/peds.2014-3354

6. Fonseca MJ, Severo M, Barros $\mathrm{H}$, et al. Determinants of weight changes during the first 96 hours of life in full-term newborns. Birth 2014;41(2):160-8.

https://doi.org/10.1111/birt.12087

7. Castilho S, Miranda AM, Fernandes CA, et al. Excess weight loss and hypernatremia in exclusively breastfed infants. J Pediatr Neonat Individual Med. 2018; 7(2):e070212.

8. Eren T. Follow-up of the weight loss in exclusively breastfed newborns before hospital discharge. PhD Thesis, Istanbul University Institute of Health Sciences and Institute of Child Health Social Pediatrics Doctoral Programme, 2018.

9. Kelly NM, Keane JV, Gallimore RB, et al. Neonatal weight loss and gain patterns in caesarean section born infants: integrative systematic review. Matern Child Nutr. 2020; 16(2):e12914 https://doi.org/10.1111/mcn.12914

10. Lewallen LP, Dick MJ, Flowers J, et al. Breastfeeding support and early cessation. J Obstet Gynecol Neonatal Nurs. 2006;35(2):166-72. https://doi.org/10.1111/j.1552-6909.2006.00031.x

11. Chen YJ, Chen WC, Chen CM. Risk factors for hyperbilirubinemia in breastfed term neonates. Eur J Pediatr. 2012; 171(1):167-71. https://doi.org/10.1007/s00431-011-1512-8

12. Livingstone $\mathrm{VH}$, Willis $\mathrm{CE}$, Abdel-Wareth LO, et al. Neonatal hypernatremic dehydration associated with breast-feeding malnutrition: a retrospective survey. CMAJ. 2000;162(5):647652.

13. Holmes AV, Auinger $P$, Howard CR. Combination feeding of breast milk and formula: Evidence for shorter breast-feeding duration from the National Health and Nutrition Examination Survey. J Pediatr. 2011;159(2):186-191. https://doi.org/10.1016/j.jpeds.2011.02.006

14. Flaherman VJ, Schaefer EW, Kuzniewicz MW,et al. Early weight loss nomograms for exclusively breastfed newborns. Pediatrics 2015;135(1):e16-23. https://doi.org/10.1542/peds.2014-1532

15. Hamilcikan Ş, Gok V, Bent S, et al. Early Weight Loss in Exclusively Breastfed Term Neonates. Iran J Pediatr. 2017;27(2):e9497. https://doi.org/10.5812/ijp.9497

16. Vogel JP, Betrán AP, Vindevoghel N, et al. WHO Multi-Country Survey on Maternal and Newborn Health Research Network. Use of the Robson classification to assess caesarean section trends in 21 countries: a secondary analysis of two WHO multicountry surveys. Lancet Glob Health. 2015;3(5):e260-70. https://doi.org/10.1016/S2214-109X(15)70094-X

17. Hacettepe University Institute of Population Studies "2018 Turkey Demographic and Health Survey". Hacettepe University Institute of Population Studies, T.R. Ministry of Development and TÜBITAK,2019, Ankara, Turkey.

18. Silva TPR, Carmo AS, Novaes TG,et al. Hospital-acquired conditions and length of stay in the pregnancy and puerperal cycle. Rev Saude Publica. 2019;53:64. https://doi.org/10.11606/s1518-8787.2019053000688

19. Saki A, Eshraghian MR, Mohammad K, et al. A prospective study of the effect of delivery type on neonatal weight gain pattern in exclusively breastfed neonates born in Shiraz, Iran. Int Breastfeed J. 2010;5:1. https://doi.org/10.1186/1746-4358-5-1

20. Breastfeeding and the Use of Human Milk. Section On Breastfeeding. Pediatrics 2012,129(3):e827-e841; https://doi.org/10.1542/peds.2011-3552

21. Dewey KG. Risk Factors for suboptimal infant breastfeeding behavior, delayed onset of lactation and excess neonatal weight loss. Pediatrics 2003;112(3):607-19. https://doi.org/10.1542/peds.112.3.607

22. Flaherman VJ, Schaefer EW, Kuzniewicz MK, et al. Newborn Weight Loss During Birth Hospitalization and Breastfeeding Outcomes Through Age 1 Month. J Hum Lact. 2017;33(1):22530. https://doi.org/10.1177/0890334416680181

23. Samayam P, Ranganathan PK, Balasundaram R. Study of Weight Patterns in Exclusively Breast Fed Neonates- Does the Route of Delivery have an Impact? J Clin Diagn Res. 2016; 10(1):SC01-SC3.

https://doi.org/10.7860/JCDR/2016/17889.7025 